\title{
Synthesis, cytotoxic and antitubercular activities of copper(II) complexes with heterocyclic bases and 3-hydroxypicolinic acid
}

\author{
Janaina do Couto Almeida ${ }^{a}$, Ivana M. Marzano ${ }^{b}$, Marcos Pivatto ${ }^{a}$, Norberto P. Lopes ${ }^{c}$, \\ Ana M. Da Costa Ferreira ${ }^{d}$, F.R. Pavan ${ }^{\text {e }}$, I.C. Silva ${ }^{\mathrm{e}}$, Elene C. Pereira-Maia ${ }^{\mathrm{b}}$, G. Von Poelhsitz ${ }^{\mathrm{a}}$, \\ Wendell Guerra ${ }^{a, *}$ \\ a Instituto de Química, Universidade Federal de Uberlândia, Uberlândia, MG, Brazil \\ b Departamento de Química, Universidade Federal de Minas Gerais, Belo Horizonte, MG, Brazil \\ ${ }^{\mathrm{c}}$ Núcleo de Pesquisa em Produtos Naturais e Sintéticos (NPPNS), Faculdade de Ciências Farmacêuticas de Ribeirão Preto, Universidade de São Paulo, 14.040-903 Ribeirão Preto, \\ SP, Brazil \\ 'Instituto de Química, Universidade de São Paulo, São Paulo, SP, Brazil \\ e Faculdade de Ciências Farmacêuticas, Departamento de Ciências Biológicas, Universidade Estadual Paulista, Campus Araraquara, 14.801-902 Araraquara, SP, Brazil
}

\section{A R T I C L E I N F O}

\section{Article history:}

Received 8 January 2016

Received in revised form 29 February 2016

Accepted 3 March 2016

Available online 9 March 2016

\section{Keywords:}

Copper complexes

$\mathrm{N}$-donor heterocyclic ligands

Antimycobacterial activity

3-Hydroxypicolinic acid

Cytotoxicity activity

\begin{abstract}
A B S T R A C T
Two new copper(II) complexes with the deprotonated ligand 3-hydroxypicolinic acid (3-HPA) and heterocyclic bases (1,10-phenanthroline - phen or 2,2'-bipyridine - bpy) were synthesized. [Cu(3-HPA)(phen) $\left.\mathrm{ClO}_{4}\right] \mathbf{I}$ and $\left[\mathrm{Cu}(3-\mathrm{HPA})(\mathrm{bpy}) \mathrm{ClO}_{4}\right]$ II were characterized by elemental analyses, conductivity measurements, FT-IR, UV-Vis, EPR and High-resolution Electrospray Ionization Mass Spectrometry (HRESIMS). The results indicate that the geometry around the copper ion is distorted square-pyramidal, and that the copper ion is coordinated to 3-HPA via oxygen and nitrogen atoms, and to heterocyclic bases via their two nitrogen atoms. A perchlorate ion weakly bonded occupies the apical position, completing the metal coordination sphere. In this work, the compound $\left[\mathrm{Cu}(3-\mathrm{HPA})_{2}\right]$ III was also synthesized using a new method, different from that described in the literature. The cytotoxic activity of these compounds against tumor and normal cell lines was investigated. Complex I exhibited a strong antitumor activity, being the most active in the series of studied complexes. The compounds were also evaluated for activity against Mycobacterium tuberculosis, and the complex I displays good antimycobacterial activity, while compounds II and III were only moderately active.
\end{abstract}

(c) 2016 Elsevier B.V. All rights reserved.

\section{Introduction}

Metal complexes are useful as drugs in the treatment of a series of diseases, mainly in cancer chemotherapy. Since the discovery of the antitumoral activity of cisplatin, cis- $\left[\mathrm{PtCl}_{2}\left(\mathrm{NH}_{3}\right)_{2}\right]$, in 1965 , a great number of coordination compounds have been synthesized and tested in order to develop clinically more effective and safe drugs [1]. Although all approved drugs are based in platinum, having a cis-[ $\mathrm{PtX}_{2}$ (amine $\left.)_{2}\right]$ chemotype (where $\mathrm{X}=$ leaving group, amine $=$ neutral or carrier group) [2], some ruthenium compounds, as KP1019 and NAMI-A, have also entered clinical tests [3]. Other examples of metal complexes as candidates to therapeutic agents include gold [4] and cobalt [5], showing different mechanisms of action. Copper is very promising in the development of new

\footnotetext{
* Corresponding author at: Instituto de Química, Universidade Federal de Uberlândia, João Naves de Ávila Avenue, 2121, Campus Santa Mônica, 38.400-902 Uberlândia, MG, Brazil. Tel.: +55 3432394143.

E-mail address: wg@iqufu.ufu.br (W. Guerra).
}

pharmacological agents, because is an essential trace element important for the function of several enzymes involved in energy metabolism, respiration and DNA synthesis in the cell, having its homeostasis strictly regulated [6,7]. Therefore, copper complexes have been investigated for many therapeutic purposes, such as antitumoral, antimalarial, antifungal, and antibacterial agents, in the treatment of Alzheimer's disease, diabetes, rheumatoid arthritis, skin wounds, cardiovascular diseases, and leishmaniasis and more recently as potential drugs to combat Parkinson's disease [8]. Two copper complexes developed by Ruiz and co-workers, are already approved for clinical trials as antitumor drugs [9], and many copper complexes with $\mathrm{N}$-donor heterocyclic ligands, such as 1,10-phenantroline and 2,2'-bipyridine were described to cleave DNA and inhibit tumoral cell growth [10-13]. We have previously reported the DNA cleavage ability of copper(II)-phenanthroline complexes with tetracycline and doxycycline [14]. These compounds inhibit the growth of a chronic myelogenous leukemia cell line and cleave DNA in mild conditions, in the absence of additional 
agents [14]. In other studies, our research group also showed that copper complexes containing $\beta$-diketones or hydrazides and $2,2^{\prime}$ bipyridine or 1,10-phenanthroline are promising antitumoral agents [15-17]. Indeed, the synthesis of new copper(II) complexes with potential pharmacological activity is highly desired.

Here, our strategy to obtain new active compounds was to use the 3-hydroxypicolinic acid (3-HPA) as ligand to synthesize complexes of the type $\left[\mathrm{Cu}(3-\mathrm{HPA})(\mathrm{N}-\mathrm{N}) \mathrm{ClO}_{4}\right]$, in which $\mathrm{N}-\mathrm{N}=1,10-$ phenantroline or 2,2'-bipyridine. The compound $\left[\mathrm{Cu}(3-\mathrm{HPA})_{2}\right]$ was also synthesized using a different method from that described in the literature. The complexes were characterized by elemental analyses, conductivity measurements, FT-IR, UV-Vis, EPR and High-resolution Electrospray Ionization Mass Spectrometry (HRESIMS). Regarding the 3-hydroxypicolinic acid, Barbosa et al. [18] reported a ruthenium(II) complex with 3-HPA that showed a good activity against Mycobacterium tuberculosis H37Rv ATCC 27294. These findings encourage us to prepare a new series of copper complexes and to evaluate its potentiality as antitumoral and antimycobacterial agents.

\section{Experimental}

\subsection{Starting materials}

The reagents (ligands and metallic salts) are commercially available (Aldrich).

\subsection{Preparation of the complexes}

The complexes with heterocyclic bases were synthesized following the same general procedure. For example, [ $\mathrm{Cu}(3-\mathrm{HPA})$ (phen) $\mathrm{ClO}_{4}$ ] was prepared by the reaction of $\mathrm{Cu}\left(\mathrm{ClO}_{4}\right)_{2} \cdot 6 \mathrm{H}_{2} \mathrm{O}$ (60.4 mg, $0.25 \mathrm{mmol}$ ) with $0.25 \mathrm{mmol}$ of 3-hydroxypicolinic acid (3-HPA) in methanol $(5 \mathrm{~mL})$. The mixture was stirred for $20 \mathrm{~min}$ followed by the slow addition of 1,10 -phenanthroline $(0.25 \mathrm{mmol})$ previously dissolved in methanol. After $48 \mathrm{~h}$, the solid formed was separated by filtration, washed with water and dried under reduced pressure.

\subsection{1. [Cu(3-HPA)(phen $\left.) \mathrm{ClO}_{4}\right]$ I}

M.M.: $481.30 \mathrm{~g} \mathrm{~mol}^{-1}$. Yield: $62 \%$. Color: Blue. Anal. Calc. for $\left(\mathrm{CuC}_{18} \mathrm{H}_{12} \mathrm{~N}_{3} \mathrm{O}_{7} \mathrm{Cl}\right)$ : C, 44.92; $\mathrm{H}, 2.51 ; \mathrm{N}, 8.73$. Found: C, 44.98; $\mathrm{H}$, 2.37; N, 8.69\%. HRESIMS (methanol), $\mathrm{m} / \mathrm{z}$ : $381.0184\left[\mathrm{M}-\mathrm{ClO}_{4}\right]^{+}$. IR $(\mathrm{KBr}) v\left(\mathrm{~cm}^{-1}\right): 3447,3105,3068,2374,2338,1653,1646$, $1637,1629,1608,1560,1522,1508,1457,1429,1397,1388$, $1340,1320,1275,1239,1219,1150,1110,1087,900,872,847$, $832,820,809,777,767,736,720,692,623,588,453$. UV-Vis (methanol), $\lambda_{\max } \quad(\mathrm{nm})=342 \quad\left(4.8 \times 10^{2} \mathrm{~mol}^{-1} \mathrm{~L} \mathrm{~cm}^{-1}\right), \quad 294$ $\left(1.9 \times 10^{3} \mathrm{~mol}^{-1} \mathrm{~L} \mathrm{~cm}^{-1}\right), \quad 272 \quad\left(4.60 \times 10^{3} \mathrm{~mol}^{-1} \mathrm{~L} \mathrm{~cm}^{-1}\right), \quad 265$ $\left(5.00 \times 10^{3} \mathrm{~mol}^{-1} \mathrm{~L} \mathrm{~cm}^{-1}\right), \quad 227\left(7.80 \times 10^{3} \mathrm{~mol}^{-1} \mathrm{~L} \mathrm{~cm}^{-1}\right), \quad 670$ $\left(3.00 \times 10^{1} \mathrm{~mol}^{-1} \mathrm{~L} \mathrm{~cm}^{-1}\right), 700$ (solid). EPR parameters, in solid: $g_{\perp} 2.051, g_{/ /} 2.164$; in frozen acetonitrile solution: $g_{\perp} 2.079, g_{/ /}$ $2.271, A_{/ /} 167 \mathrm{G}$, or $177 \cdot 10^{-4} \mathrm{~cm}^{-1}, g_{/ /} / A_{/ /}, 128 \mathrm{~cm}$. Molar conductivity, $\Lambda \mathrm{M}($ ethanol $)=39.12 \mu \mathrm{S} \mathrm{cm}^{-1}$.

\subsection{2. $\left[\mathrm{Cu}(3-\mathrm{HPA})(\mathrm{bpy}) \mathrm{ClO}_{4}\right] \mathbf{I I}$}

M.M.: $457.2814 \mathrm{~g} \mathrm{~mol}^{-1}$. Yield: $50 \%$. Color: Blue. Anal. Calc. for $\left(\mathrm{CuC}_{16} \mathrm{H}_{12} \mathrm{~N}_{3} \mathrm{O}_{7} \mathrm{Cl}\right)$ : C, 42.02; H, 2.65; N, 9.19. Found: C, 41.77; H, 2.37; N, 9.01\%. HRESIMS (ethanol), $m / z: 357.0176\left[\mathrm{M}-\mathrm{ClO}_{4}\right]^{+}$. IR $(\mathrm{KBr}) v\left(\mathrm{~cm}^{-1}\right): 3450,2375,2344,1653,1647,1637,1629,1624$, $1616,1608,1473,1465,1458,1448,1319,1276,1240,1217,1152$, 1122, 1089, 899, 832, 819, 809, 769, 729, 691, 621, 590, 452. UV-Vis (ethanol), $\lambda_{\max }(\mathrm{nm})=309\left(1.30 \times 10^{4} \mathrm{~mol}^{-1} \mathrm{~L} \mathrm{~cm}^{-1}\right), 297$ $\left(1.50 \times 10^{4} \mathrm{~mol}^{-1} \mathrm{~L} \mathrm{~cm}^{-1}\right), \quad 224\left(2.63 \times 10^{4} \mathrm{~mol}^{-1} \mathrm{~L} \mathrm{~cm}^{-1}\right), \quad 661$ $\left(3.10 \times 10^{1} \mathrm{~mol}^{-1} \mathrm{~L} \mathrm{~cm}^{-1}\right), \quad 633 \quad$ (solid). $\quad 1 \mathrm{M} \quad$ (ethanol) $=35.93 \mu \mathrm{S} \mathrm{cm}^{-1}$.

\subsection{3. [Cu(3-HPA $\left.)_{2}\right]$ III}

This complex was synthesized by Girginova et al. using a different method [19]. In this work, [Cu(3-HPA $)_{2}$ ] was prepared by the reaction of $\mathrm{Cu}\left(\mathrm{ClO}_{4}\right)_{2} \cdot 6 \mathrm{H}_{2} \mathrm{O}(60.4 \mathrm{~g}, 0.25 \mathrm{mmol})$ with $0.50 \mathrm{mmol}$ of 3-hydroxypicolinic acid (3-HPA) in methanol $(5 \mathrm{~mL})$. The mixture was stirred for $48 \mathrm{~h}$ and the crystalline solid formed was separated by filtration, washed with water and dried under reduced pressure.

M.M.: $339.7477 \mathrm{~g} \mathrm{~mol}^{-1}$. Yield: 51\%. Color: Dark blue. Anal. Calc. for $\left(\mathrm{CuC}_{12} \mathrm{H}_{8} \mathrm{~N}_{2} \mathrm{O}_{6}\right)$ : C, 42.42; $\mathrm{H}, 2.37 ; \mathrm{N}, 8.25$. Found: C, 42.84; $\mathrm{H}$, 2.51 ; N, 8.13\%. IR (KBr) $v\left(\mathrm{~cm}^{-1}\right): 3453,3100,3069,2376,2344$, $1653,1647,1608,1576,1570,1559,1508,1456,1394,1388$, $1321,1309,1275,1240,1217,1153,1128,1058,903,833,819$, $810,765,691,588,452$. UV-Vis (ethanol), $\lambda_{\max }(\mathrm{nm})=302$ $\left(1.21 \times 10^{4} \mathrm{~mol}^{-1} \mathrm{~L} \mathrm{~cm}^{-1}\right), \quad 653 \quad\left(3.5 \times 10^{1} \mathrm{~mol}^{-1} \mathrm{~L} \mathrm{~cm}^{-1}\right), \quad 598$ (solid). $\Lambda \mathrm{M}$ (ethanol) $=0.69 \mu \mathrm{S} \mathrm{cm}^{-1}$.

\subsection{Physical measurements}

Conductivity studies were carried out with a Digimed DM 31 conductivity meter using a cell of constant $0.95 \mathrm{~cm}^{-1}$, and spectroscopic grade ethanol $\left(\Lambda \mathrm{M}=0.93 \mu \mathrm{S} \mathrm{cm}^{-1}\right)$ as solvent.

Elemental analyses were performed using a Perkin-Elmer 2400 CHN Elemental Analyser.

IR spectra were registered in $\mathrm{KBr}$ pellets on a Shimadzu FTIR-Irprestige-21 spectrometer.

Diffuse reflectance spectra and UV-Vis were obtained on a Shimadzu UV-2501 PC spectrophotometer.

High-resolution Electrospray Ionization Mass Spectrometry (HRESIMS) were measured on an ultrOTOF (Bruker Daltonics) spectrometer, operating in the positive mode. Methanol-water $(1: 1, v / v)$ was used as solvent system and the samples were infused into the ESI source at a flow rate of $5 \mu \mathrm{L} / \mathrm{min}$. The calculated values for the charged complex ions were made using ChemDraw Ultra 14.0.

For the EPR spectra registration, a Bruker instrument (Karlsruhe, Germany), model EMX, operating at X-band $(9.50 \mathrm{GHz}$ frequency, $20 \mathrm{~mW}$ power, $100 \mathrm{kHz}$ modulation frequency) was used. Measurements were performed at $77 \mathrm{~K}$, with samples in solid state or in frozen acetonitrile solution, using Wilmad quartz tubes. DPPH ( $\alpha, \alpha^{\prime}$-diphenyl- $\beta$-picrylhydrazyl) was used for frequency calibration $(g=2.0036)$.

\subsection{Cells and culture}

\subsubsection{K562 cells}

The K562 cell line was purchased from the Rio de Janeiro Cell Bank (number CR083 of the RJCB collection). This cell line was established from pleural effusion of a 53 year-old female with chronic myelogenous leukemia in terminal blast crisis. Cells were cultured in RPMI 1640 (Sigma Chemical Co.) medium supplemented with $10 \%$ fetal calf serum (CULTILAB, São Paulo, Brazil) at $37{ }^{\circ} \mathrm{C}$ in a humidified $5 \% \mathrm{CO}_{2}$ atmosphere. Cultures grow exponentially from $10^{5}$ cells $\mathrm{mL}^{-1}$ to about $8 \times 10^{5}$ cells $\mathrm{mL}^{-1}$ in three days. Cell viability was checked by Trypan Blue exclusion. The cell number was determined by coulter counter analysis.

For cytotoxicity assessment, $1 \times 10^{5}$ cells $\mathrm{mL}^{-1}$ was cultured for $72 \mathrm{~h}$ in the absence and presence of a range of concentrations of tested compounds. The sensitivity to compound was evaluated by the concentration that inhibits cell growth by $50 \%\left(\mathrm{IC}_{50}\right)$. Stock solutions were prepared in DMSO and diluted accordingly to obtain the concentrations used in the cytotoxic assays. The final concentration of DMSO in the experiments was below $0.5 \%$ and we have checked that the solvent has no effect on cell growth at this concentration. 


\subsubsection{MRC-5 and A549 cells}

MRC-5 (normal fibroblast pulmonary cells) and A549 (human lung adenocarcinoma epithelial) cells line were obtained from the American Type Culture Collection (Manassas, VA, USA), and incubated in DMEM medium with supplemented with $10 \%$ FBS and $1 \%$ penicillin $(100 \mathrm{U} / \mathrm{ml})$-streptomycin $(100 \mu \mathrm{g} / \mathrm{ml})$. Cells were maintained in a humidified environment at $37{ }^{\circ} \mathrm{C}$ with $5 \% \mathrm{CO}_{2}$ and sub-cultured twice per week.

A resazurin reduction assay was used to investigate cytotoxicity of several drugs toward MRC-5 and A549 cells. The assay is based on reduction of the indicator dye, resazurin, to the highly fluorescent resorufin by viable cells. Nonviable cells rapidly lose the metabolic capacity to reduce resazurin and thus do not produce a fluorescent signal.

Briefly, the cells were detached by treatment with $0.25 \%$ tryp$\sin /$ EDTA (VitroCell, Brazil) and $2.5 \times 10^{4}$ cells were placed in each well of a 96-well cell culture plate (Costar, USA) in a total volume of $100 \mu$ l. Cells were allowed to adhere overnight and then were treated with different concentrations of drugs. After $24 \mathrm{~h}$ or $72 \mathrm{~h}$ incubation in the presence of the compounds, the medium was removed and $50 \mu \mathrm{l}$ resazurin (Sigma-Aldrich, Germany) $0.01 \% \mathrm{w} /$ $\mathrm{v}$ in DMEM, was added to each well and the plates were incubated at $37^{\circ} \mathrm{C}$ for $3 \mathrm{~h}$.

The fluorescence was measured on Biotek Synergy $\mathrm{H} 1$ plate reader (Biotek, Winooski, VT) using an excitation wavelength of $530 \mathrm{~nm}$ and an emission wavelength of $590 \mathrm{~nm}$. Untreated cells constituted the negative control (viable cells), and cells treated with doxorubicin at $100 \mathrm{nmol}$ (Sigma-Aldrich, St. Louis, MO, USA) constituted the positive control (death control, DC). All the tests were performed in three independents assays. A test was done on plates without cells to verify that the reaction cannot occur between the compounds and the reagent to avoid false-positive results (data not shown).

The $\mathrm{IC}_{50}$ values represent the samples concentrations required to inhibit $50 \%$ of cell proliferation and were calculated from a calibration curve by regression curves using Microsoft Excel.

\subsection{Anti-Mycobacterium tuberculosis activity assay}

The anti-MTB activity of the compounds was determined by the REMA (Resazurin Microtiter Assay) method [20]. Stock solutions of the tested compounds were prepared in DMSO and diluted in Middlebrook 7H9 broth (Difco) supplemented with oleic acid, albumin, dextrose and catalase (OADC), performed by Precision XS (Biotek ${ }^{\circledR}$ ) to obtain the final drug concentration range of $0.09-25 \mu \mathrm{g} / \mathrm{mL}$. Isoniazid was dissolved in distilled water and rifampicin in DMSO, and both were used as standard drugs. A suspension of MTB $\mathrm{H}_{37}$ Rv ATCC 27294 was cultured in Middlebrook 7H9 broth supplemented with OADC and $0.05 \%$ Tween 80 . The cultures were frozen at $-80^{\circ} \mathrm{C}$ in aliquots. After two days the CFU per $\mathrm{mL}$ (colony formation unit per $\mathrm{mL}$ ) of an aliquot was determined. The concentrations were adjusted by $5 \times 10^{5} \mathrm{CFU}$ per $\mathrm{mL}$ and $100 \mu \mathrm{L}$ of the inoculum were added to each well of a 96-well microplate (Kasvi ${ }^{\circledR}$ ) together with $100 \mu \mathrm{L}$ of the compounds. Samples were set up in triplicate. The plates were incubated for 7 days at $37^{\circ} \mathrm{C}$. Resazurin (solubilized in water) was added ( $30 \mu \mathrm{L}$ of $0.01 \%)$. The fluorescence of the wells was read after $24 \mathrm{~h}$ with a Cytation 3 (Biotek ${ }^{\circledR}$ ). The MIC was defined as the lowest concentration resulting in $90 \%$ inhibition of growth of MTB.

\section{Results and discussion}

Copper(II) complexes with the deprotonated ligand 3-hydroxypicolinic acid (3-HPA) were synthesized and characterized by elemental analyses, conductivity measurements, FT-IR, UV-Vis,
High-resolution Electrospray Ionization Mass Spectrometry (HRESIMS) and EPR. All the copper complexes are colourful, non hygroscopic, stable to air and light and soluble in organic solvents such as DMSO, ethanol and acetonitrile. The chemical structures of the complexes with 3-HPA are presented in Fig. 1.

The results of the elemental analyses are in good agreement with the proposed structures. The molar conductivity values of solutions $\left(10^{-3} \mathrm{M}\right.$; ethanol) for all complexes with heterocyclic bases fall in the range observed for 1:1 electrolytes [21]. The labilization of the axial ligands in solution (perchlorate anion) results in the generation of compounds of type $[\mathrm{Cu}(3-\mathrm{HPA})(\mathrm{N}-\mathrm{N})]^{+}$. On the other hand, as expected, the molar conductivity value for III indicates that this compound is nonelectrolyte. The crystal structure of the complex III has been described in the literature [19] and it will not be discussed further here. Nevertheless, for this complex, the metal ion is coordinated to two N,O-chelating anionic ligands and exhibits a distorted square planar coordination geometry [19].

The high-resolution mass spectra of the synthesized complexes were performed and the obtained data are according to the proposed structures. In this work, the $m / z$ values listed in the text (see Section 2) refer to the peak containing the most abundant isotope $\left({ }^{63} \mathrm{Cu}\right)$. For example, mass spectrum of the complex II (Fig. S1) exhibited the charged ion at $\mathrm{m} / z 357.0176\left[\mathrm{M}-\mathrm{ClO}_{4}\right]^{+}$(calcd. 357.0175). The experimental isotopic patterns for [Cu(3-HPA) (bpy) $]^{+}$and $[\mathrm{Cu}(3-\mathrm{HPA})(\text { phen })]^{+}$ions match the theoretical isotopic patterns considering the proposed compositions.

The UV-Vis spectra of the complexes were recorded in ethanol $\left(10^{-4} \mathrm{M}\right)$ in the range of $200-900 \mathrm{~nm}$. A bathochromic shift in relation to free ligands confirms the presence of the complexes in solution. The absorption spectra of the complex II and of the corresponding ligands are shown in Fig. 2. The splitting observed in the spectrum of the complex is also consistent with the coordination of the ligand to metal. Complexes I and II exhibit only one broad and asymmetric $\mathrm{d}-\mathrm{d}$ band centered at $\approx 660 \mathrm{~nm}$. For example, the complex II exhibits a d-d band (Fig. S2) centered at $661 \mathrm{~nm}\left(\varepsilon=31 \mathrm{~mol}^{-1} \mathrm{~L} \mathrm{~cm}^{-1}\right)$. These observations are consistent with a distortion from the square-pyramidal geometry, due to the Jahn-Teller effect [15]. In the solid state (diffuse reflectance), the complexes I and II exhibit the d-d band centered at 633 and $700 \mathrm{~nm}$, respectively, indicating that the geometry of the complexes in solution differs from that in solid state [17].

The IR spectra of the new complexes are in accordance with the presence of 3-HPA coordinated to the copper(II) ions via the carboxylate group and nitrogen. The carboxylate group may coordinate to a metal atom in one of the unidentate, bidentate or bridging modes. For all complexes, bands corresponding to the $\operatorname{vas}\left(\mathrm{COO}^{-}\right)$and $\mathrm{vs}\left(\mathrm{COO}^{-}\right)$vibrational modes appeared close to $1654\left(1703 \mathrm{~cm}^{-1}\right.$ in the uncoordinated ligand) and $1320 \mathrm{~cm}^{-1}$ (1295 $\mathrm{cm}^{-1}$ in the uncoordinated ligand), respectively. The value of $\Delta(v a s-v s)=331 \mathrm{~cm}^{-1}$ indicates the presence of monodentate carboxylate group. Peaks of medium intensity around $1580 \mathrm{~cm}^{-1}$ are assigned to $\mathrm{v}(\mathrm{C}=\mathrm{N})$ of the coordinated ligand, in good agreement with the N,O-chelation [19,22]. The same coordination mode was observed in previous works for some complexes containing 3HPA as ligands [18,19,22-24]. The stretching vibrations of the uncoordinated hydroxyl group of ligand appear in the range $3448-3455 \mathrm{~cm}^{-1}$. The weak bands at 3100 and $3000 \mathrm{~cm}^{-1}$ are attributed to the stretching vibrations of aromatic $\mathrm{C}-\mathrm{H}$ bonds. Infrared spectroscopy is very useful to determine the mode of coordination of the $\mathrm{ClO}_{4}$ ligand. The behavior of the weakly coordinating perchlorate ion can be distinguished by the $\mathrm{Cl}-\mathrm{O}$ stretching frequencies [14]. The infrared spectra of I and II indicate the presence of one unidentate perchlorate ion. Bands in the region $578-559$ and $443-437 \mathrm{~cm}^{-1}$ were assigned to $\mathrm{vCu}-\mathrm{N}$ and vCu-O. 


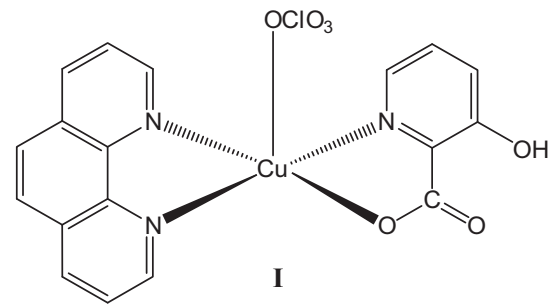<smiles></smiles><smiles></smiles>

Fig. 1. Proposals structures for the complexes I-III.

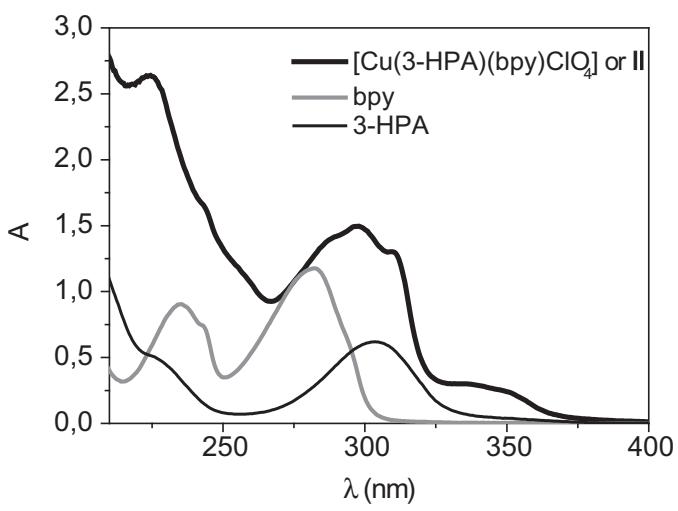

Fig. 2. Electronic spectra of $\left[\mathrm{Cu}(3-\mathrm{HPA})(\mathrm{bpy}) \mathrm{ClO}_{4}\right], 3-\mathrm{HPA}$, and bpy, in ethanol $\left(1.0 \times 10^{-4} \mathrm{M}\right)$.

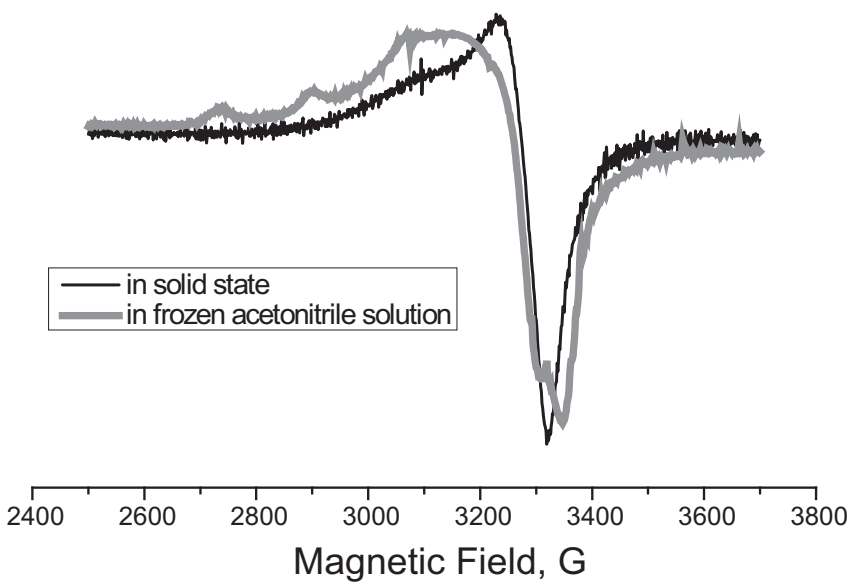

Fig. 3. EPR spectra of the complex I (solution and in solid-state).

EPR spectra for complex I (Fig. 3) in solid state and in frozen acetonitrile solution corroborate the change of geometry observed in electronic spectra. In the solid, a perchlorate anion is bound at the apical position, providing a penta-coordinate environment around the metal ion, while in solution a tetragonal geometry with little tetrahedral distortion is observed, as indicated by the spectroscopic parameters ratio obtained, $g_{/ /} / A_{/ /}(128 \mathrm{~cm})[17,25]$ (see Table 1).
Table 1

EPR spectroscopic parameters.

\begin{tabular}{llllll}
\hline Compound & $g_{\perp}$ & $g_{/ /}$ & $\begin{array}{l}A_{/ /} \\
(\mathrm{G})\end{array}$ & $\begin{array}{l}A_{/ /} \\
\left(10^{-4} \mathrm{~cm}^{-1}\right)\end{array}$ & $\begin{array}{l}g_{/ /} / \mathrm{A}_{/ /} \\
(\mathrm{cm})\end{array}$ \\
\hline $\begin{array}{l}{\left[\mathrm{Cu}(3-\mathrm{HPA})\left(\text { Phen) } \mathrm{ClO}_{4}\right] \mathbf{I}\right.} \\
\begin{array}{c}\text { In frozen acetonitrile } \\
\text { solution }\end{array}\end{array}$ & 2.079 & 2.271 & 167 & 177 & 128 \\
\begin{tabular}{l} 
In solid state \\
\hline
\end{tabular} & 2.050 & 2.162 & & & \\
\hline
\end{tabular}

\subsection{Stability of complexes}

Stability is a very important factor for the development of clinical metal complexes [13]. Thus, the stability of the complex I was evaluated by UV-Vis spectral analysis at different times in a mixture containing $\mathrm{H}_{2} \mathrm{O} / \mathrm{DMSO}(1: 99 \mathrm{v} / \mathrm{v})$. According to the Fig. 4, the values of absorbance and wavelength were not affected. These observations indicate that the complex is stable in solution for at least $8 \mathrm{~h}$ under the test conditions [26].

\subsection{Cytotoxic studies}

The cytotoxic activity of compounds is depicted in Table $2 . \mathrm{IC}_{50}$ values obtained for two platinum complexes used in chemotherapy, cisplatin and carboplatin, are also shown for the sake of comparison.

As it can be seen in Table 2, phenanthroline (phen) displays high activity and selectivity index (SI) against the K562 cell line.

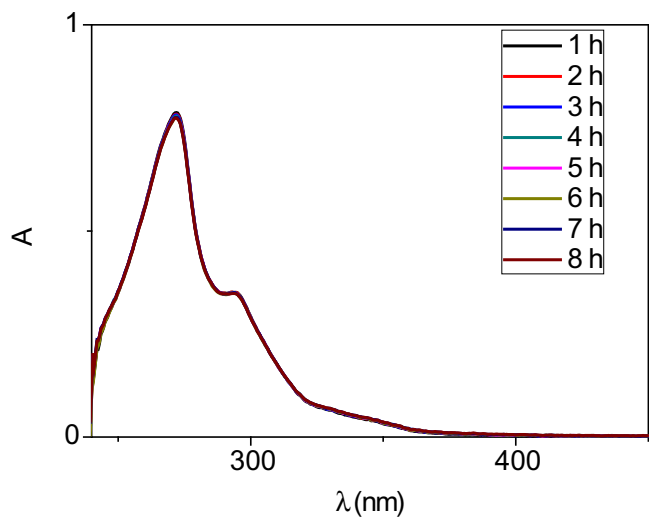

Fig. 4. Ultraviolet spectra of complex I as a function of time. 
Table 2

${ }^{\mathrm{a}} \mathrm{IC}_{50}(\mu \mathrm{M})$ values for ligands, cisplatin, carboplatin and complexes.

\begin{tabular}{lllllll}
\hline Compound & $\begin{array}{l}\text { K562 } \\
(72 \mathrm{~h})\end{array}$ & $\begin{array}{l}\text { MRC-5 } \\
(72 \mathrm{~h})\end{array}$ & ${ }^{\mathrm{b}} \mathrm{SI}$ & $\begin{array}{l}\text { MRC-5 } \\
(24 \mathrm{~h})\end{array}$ & $\begin{array}{l}\text { A549 } \\
(24 \mathrm{~h})\end{array}$ & ${ }^{\mathrm{b}}$ SI \\
\hline 3-HPA & 130.0 & 2767.6 & 21.3 & 2228.4 & 2264.4 & 0.9 \\
phen & 3.2 & 166.4 & 52 & 305.0 & 77.6 & 3.9 \\
bpy & 30.0 & $>2560.9$ & $>85.4$ & 320.1 & $>2560.9$ & $<0.12$ \\
I & 2.3 & 0.4 & 0.17 & 4.8 & 8.3 & 0.6 \\
II & 21.8 & 32.8 & 1.50 & 43.7 & 52.5 & 0.8 \\
III & 20.8 & 70.6 & 3.40 & 53.0 & 82.4 & 0.6 \\
Carboplatin & 10.0 & - & & - & - & - \\
Cisplatin & 1.1 & - & & - & - & - \\
\hline
\end{tabular}

K562: chronic myelogenous leukemia cell line.

MRC-5: lung cell line (normal).

A549: human lung adenocarcinoma epithelial cell line.

${ }^{a} \mathrm{IC}_{50}$ - concentration required to inhibit $50 \%$ of cell growth.

b SI - selectivity index.

However, in the literature, for the phenanthroline and its derivatives, it is assumed that the sequestering of trace metals in situ is involved and that the resulting metallic complexes are the active species [27]. All organic compounds exhibited low activity against A549 and MRC-5.

The copper complexes inhibit the growth of $\mathrm{K} 562$ and A549 cells with $\mathrm{IC}_{50}$ values between 2.3 and $82.4 \mu \mathrm{M}$. The results showed that activity of the complexes follows the order I $>$ II $=$ III. Copper coordination improves the cytotoxic activity: all complexes are more potent than the corresponding free ligands. The substitution of one molecule of 3-HPA by one molecule of phen significantly increases the cytotoxic activity; though, it does not improve the selectivity index, which is low and suggests a generic toxicity. Regarding the complexes I and II, compared to similar compounds containing aromatic diimine ligands $(\mathrm{N}-\mathrm{N})$ already described, they show very similar results, as shown in Table 3. In the complexes with heterocyclic bases, the substitution of bpy by phen increases the activity. As a general behaviour of those aromatic diamine ligands, copper complexes with phenanthroline are more reactive than similar ones with bipyridine ligands $[8 c, 14]$. An accepted explanation for this order of reactivity is that the planar polycyclic phen ring interacts better with DNA [28]. However, the mode of action of these complexes can be quite different. Casiopeines $[\mathrm{Cu}$ $(\mathrm{N}-\mathrm{N}) \mathrm{L}] \mathrm{X}$, for example, have been described as interacting with mitochondria, inhibiting oxidative phosphorylation and, eventually, also cellular ATP depletion, in addition to DNA binding [30].

Table 3

Comparison of the cytotoxicity of different copper complexes with the chemotype [Cu $(\mathrm{N}-\mathrm{N}) \mathrm{L}] \mathrm{X}$ (where $\mathrm{N}-\mathrm{N}=1,10$-phen or $2,2^{\prime}$-bpy, and $\mathrm{X}=$ counterion, $\mathrm{NO}_{3}^{-}$, or $\mathrm{ClO}_{4}^{-}$).

\begin{tabular}{|c|c|c|c|}
\hline Complex & $\begin{array}{l}\mathrm{IC}_{50} \\
(\mu \mathrm{mol} / \mathrm{L})\end{array}$ & Cytotoxicity & References \\
\hline $\begin{array}{l}\text { [Cu(3-hydroxypicolinic acid) (phen) } \\
\left.\quad \mathrm{ClO}_{4}\right]\end{array}$ & $2.3 \pm 0.2$ & K562 cells & This work \\
\hline $\begin{array}{l}\text { [Cu(3-hydroxypicolinic acid) (bpy) } \\
\left.\mathrm{ClO}_{4}\right]\end{array}$ & $21.8 \pm 2.2$ & K562 cells & This work \\
\hline$\left[\mathrm{Cu}(\mathrm{BTA})(\right.$ phen $\left.) \mathrm{NO}_{3}\right]$ & $2.9 \pm 0.3$ & K562 cells & [17] \\
\hline$\left[\mathrm{Cu}(\mathrm{BTA})(\mathrm{bpy}) \mathrm{NO}_{3}\right]$ & $13.7 \pm 1.4$ & K562 cells & [17] \\
\hline$\left[\mathrm{Cu}(\mathrm{BTACl})(\right.$ phen $\left.) \mathrm{NO}_{3}\right]$ & $2.1 \pm 0.2$ & K562 cells & [17] \\
\hline$\left[\mathrm{Cu}(\mathrm{BTACl})(\mathrm{bpy}) \mathrm{NO}_{3}\right]$ & $9.2 \pm 1.0$ & K562 cells & [17] \\
\hline $\begin{array}{l}{[\mathrm{Cu} \text { (doxycycline })(1,10 \text {-phen })\left(\mathrm{H}_{2} \mathrm{O}\right)} \\
\quad\left(\mathrm{ClO}_{4}\right) \mathrm{ClO}_{4}\end{array}$ & $1.93 \pm 0.2$ & K562 cells & [14] \\
\hline $\begin{array}{l}{\left[\mathrm{Cu}(\text { tetracycline })(1,10 \text {-phen })\left(\mathrm{H}_{2} \mathrm{O}\right)\right.} \\
\left.\quad\left(\mathrm{ClO}_{4}\right)\right] \mathrm{ClO}_{4}\end{array}$ & $2.59 \pm 0.3$ & K562 cells & {$[14]$} \\
\hline \multirow[t]{2}{*}[\mathrm{Cu}(\text{phen})(\alpha\text{-glycinate})]{$\mathrm{NO}_{3}$} & $13.9 \pm 1.3$ & HeLa & [28] \\
\hline & $27.3 \pm 2.2$ & MCF-7 & \\
\hline [Cu(5,6-dimethylphen) & $5.3 \pm 0.1$ & HeLa & [28] \\
\hline ( $\alpha$-glycinate) $]_{\mathrm{NO}_{3}}$ & $4.4 \pm 0.3$ & MCF-7 & \\
\hline $\begin{array}{l}\mathrm{Cu}(4,7 \text {-dimethylphen)(glycinate)] } \\
\mathrm{NO}_{3}\end{array}$ & 6 & A549 & [29] \\
\hline
\end{tabular}

Table 4

Anti-MTB activity (MIC) of the copper complexes and their free ligands.

\begin{tabular}{lcc}
\hline Compound & $\mathrm{MIC}_{90}(\mu \mathrm{g} / \mathrm{mL})$ & $\mathrm{MIC}_{90}(\mu \mathrm{M})$ \\
\hline phen & 4.1 & 22.7 \\
bpy & $>25$ & $>160.0$ \\
$3-\mathrm{HPA}$ & $>25$ & 179.7 \\
{$\left[\mathrm{Cu}(3-\mathrm{HPA})(\right.$ phen $\left.) \mathrm{ClO}_{4}\right] \mathbf{I}$} & 11.9 & 24.72 \\
{$\left[\mathrm{Cu}(3-\mathrm{HPA})(\mathrm{bpy}) \mathrm{ClO}_{4}\right] \mathbf{I I}$} & $>25$ & $>54.7$ \\
{$\left[\mathrm{Cu}(3-\mathrm{HPA})_{2}\right]$ III } & 24.2 & 71.23 \\
\hline
\end{tabular}

\subsection{Anti-M. tuberculosis activity}

The antimycobacterial activity of compounds was evaluated in vitro against $M$. tuberculosis H37Rv strains by the REMA (Resazurin Microtiter Assay) method. As can be seen in Table 4, phen shows good activity against the $M$. tuberculosis H37Rv strain with MIC value equal to $22.7 \mu \mathrm{M}$. Regarding the phenanthroline (phen), this molecule and its derivatives have been identified as new agents with antimycobacterial activity [24,31,32]. Concerning the complexes, the results showed that the activity of the complex I was higher than that of free 3-HPA, displaying good antimycobacterial activity, while compounds II and III were only moderately active. Regarding the activity of compound I, this should be more lipophilic than complex II, consequently it has a higher ability to diffuse into the cell membrane and reach their biological target [33].

\section{Concluding remarks}

Two new copper(II) complexes containing 3-hydroxypicolinic acid and heterocyclic bases were prepared and characterized. For these complexes, the results indicate a distorted square-pyramidal geometry around the copper ion in the solid, where the copper ion is penta-coordinated to 3-HPA ligand via their oxygen and nitrogen atoms, and to the heterocyclic bases by its nitrogen atoms. The axial position is occupied by a perchlorate ion. However, in solution this anion acts only as counter-ion, and the geometry around copper becomes tetragonal, as attested by UV-Vis and EPR spectra (in the case of $[\mathrm{Cu}(3-\mathrm{HPA})(\mathrm{Phen})] \mathrm{ClO}_{4}$ species). The biological activities of the copper complexes make them good candidates for further studies, once small structural modifications may result in an increase of the selectivity index. Indeed, these complexes can be useful for the design of new antitumoral and antibacterial agents.

\section{Acknowledgments}

To CNPq (Conselho Nacional de Desenvolvimento Científico e Tecnológico, Brazil), FAPEMIG (Fundação de Amparo à Pesquisa de Minas Gerais, Brazil), and INCT-Catálise by financial support and fellowships. The authors are also thankful to the Grupo de Materiais Inorgânicos do Triângulo - GMIT research group supported by FAPEMIG (APQ-00330-14). This work is a collaboration research project of members of the Rede Mineira de Química (RQ-MG) supported by FAPEMIG (Project: CEX - RED-00010-14).

\section{Appendix A. Supplementary material}

Supplementary data associated with this article can be found, in the online version, at http://dx.doi.org/10.1016/j.ica.2016.03.005.

\section{References}

[1] F. Trudu, F. Amato, P. Vaňhara, T. Pivetta, E.M. Peña-Méndez, J. Havel, J. Appl. Biomed. 13 (2015) 79.

[2] N.P. Farrell, Chem. Soc. Rev. (2015), http://dx.doi.org/10.1039/c5cs00201j. 
[3] R. Trondl, P. Heffeter, C.R. Kowol, M.A. Jakupec, W. Berger, B.K. Keppler, Chem. Sci. 5 (2014) 2925.

[4] T. Zou, C.T. Lum, C.-N. Lok, J.-J. Zhang, C.-M. Che, Chem. Soc. Rev. (2015), http:// dx.doi.org/10.1039/c5cs00132c.

[5] M.C. Heffern, N. Yamamoto, R.J. Holbrook, A.L. Eckermann, T.J. Meade, Curr. Opin. Chem. Biol. 17 (2013) 189.

[6] C. Duncan, A.R. White, Metallomics 4 (2012) 127.

[7] (a) A.K. Boal, A.C. Rosenzweig, Chem. Rev. 109 (2009) 4760;

(b) M.J. Burkitt, Arch. Biochem. Biophys. 394 (2001) 117;

(c) E.R. Stadtman, R.L. Levine, Amino Acids 25 (2003) 207.

[8] (a) S. Medici, M. Peana, V.M. Nurchi, J.I. Lachowicz, G. Crisponi, M.A. Zoroddu, Coord. Chem. Rev. 284 (2015) 329;

(b) C. Santini, M. Pellei, V. Gandin, M. Porchia, F. Tisato, C. Marzano, Chem. Rev. 114 (2014) 815.

[9] R. Galindo-Murillo, J.C. García-Ramos, L. Ruiz-Azuara, T.E. Cheatham, F. CortésGuzmán, Nucleic Acids Res. 4 (2015) 5364.

[10] C. Marzano, M. Pellei, F. Tisato, C. Santini, Anticancer Agents Med. Chem. 9 (2009) 185.

[11] L. Ruiz-Azuara, M.E. Bravo-Gomez, Curr. Med. Chem. 17 (2010) 3606.

[12] S. Tardito, L. Marchio, Curr. Med. Chem. 16 (2009) 1325.

[13] F. Tisato, C. Marzano, M. Porchia, M. Pellei, C. Santini, Med. Res. Rev. 30 (2010) 708.

[14] P.P. Silva, W. Guerra, J.N. Silveira, A.M.D.C. Ferreira, T. Bortolotto, F.L. Fischer, H. Terenzi, A. Neves, E.C. Pereira-Maia, Inorg. Chem. 50 (2011) 6414.

[15] P.S. Lopes, D.A. Paixão, F.C.S. de Paula, A.M.D.C. Ferreira, J. Ellena, S. Guilardi, E. C. Pereira-Maia, W. Guerra, J. Mol. Struct. 1034 (2013) 84

[16] P.P. Silva, W. Guerra, G.C. dos Santos, N.G. Fernandes, J.N. Silveira, A.M. da Costa Ferreira, T. Bortolotto, H. Terenzi, A.J. Bortoluzzi, A. Neves, E.C. PereiraMaia, J. Inorg. Biochem. 132 (2014) 67.

[17] J.C. Almeida, D.A. Paixão, I.M. Marzano, J. Ellena, M. Pivatto, N.P. Lopes, A.M.D. C. Ferreira, E.C. Pereira-Maia, S. Guilardi, W. Guerra, Polyhedron 89 (2015) 1.

[18] M.I.F. Barbosa, R.S. Corrêa, L.V. Pozzi, E.O. Lopes, F.R. Pavan, C.Q.F. Leite, J. Ellena, S.P. Machado, G.V. Poelhsitz, A.A. Batista, Polyhedron 85 (2015) 376.
[19] P.I. Girginova, F.A.A. Paz, H.I.S. Nogueira, N.J.O. Silva, V.S. Amaral, J. Klinowski, T. Trindade, J. Mol. Struct. 737 (2005) 221.

[20] J.C. Palomino, A. Martin, M. Camacho, H. Guerra, J. Swings, F. Portaels, Antimicrob. Agents Chemother. 46 (2002) 2720.

[21] W. Geary, Coord. Chem. Rev. 7 (1971) 81.

[22] C. Sun, X. Zheng, L.P. Jin, J. Mol. Struct. 646 (2003) 201.

[23] M. Boris-Marko Kukovec, Croat. Chem. Acta 85 (2012) 479.

[24] F.R. Pavan, G.V. Poelhsitz, M.I.F. Barbosa, S.R.A. Leite, Alzir.A. Batista, J. Ellena, L. S. Sato, S.G. Franzblau, V. Moreno, D. Gambino, C.Q.F. Leite, Eur. J. Med. Chem. 46 (2011) 5099.

[25] J.C. García-Ramos, R. Galindo-Murillo, A. Tovar-Tovar, A.L. Alonso-Saenz, V. Gómes-Vidales, M. Flores-Álamo, L. Ortiz-Frade, F. Cortes-Guzmán, R. MorenoEsparza, A. Campero, L. Ruiz-Azuara, Chem. Eur. J. 20 (2014) 13730.

[26] B. Li-Jun Li, Inorg. Chim. Acta 419 (2014) 135.

[27] (a) R.A. MacLeod, J. Biol. Chem. 197 (1952) 751;

(b) F.P. Dwyer, I.K. Reid, A. Shulman, G.M. Laycock, S. Dixon, Aust. J. Exp. Biol. Med. Sci. 47 (1969) 203;

(c) M. McCann, A.L.S. Santos, B.A. da Silva, M.T.V. Romanos, A.S. Pyrrho, M. Devereux, K. Kavanagh, I. Fichtner, A. Kellet, Toxicol. Res. 1 (2012) 47.

[28] M.E. Bravo-Gómez, J.C. García-Ramos, I. Gracia-Mora, L. Ruiz-Azuara, J. Inorg. Biochem. 103 (2009) 299.

[29] R. Kachadourian, H.M. Brechbuhl, L. Ruiz-Azuara, I. Gracia-Mora, B.J. Day, Toxicology 268 (2010) 176.

[30] A. Marín-Hernandez, I. Gracia-Mora, L. Ruiz-Ramírez, R. Moreno-Sanchez, Biochem. Pharmacol. 65 (2003) 1979.

[31] R. Danac, C.M.A. Matarneh, S. Shova, T. Daniloaia, M. Balan, I.I. Mangalagiu, Bioorg. Med. Chem. 23 (2015) 2318.

[32] R. Danac, I.I. Mangalagiu, Eur. J. Med. Chem. 74 (2014) 664.

[33] J.C. Almeida, I.M. Marzano, F.C. Silva de Paula, M. Pivatto, N.P. Lopes, P.C. de Souza, F.R. Pavan, A.L.B. Formiga, E.C. Pereira-Maia, W. Guerra, J. Mol. Struct. 1075 (2014) 370. 